\section{Introduction}

In one of the first comprehensive studies of the Grameen Bank (GB), Hossain (1988) found that GB members belonged almost entirely to the target group defined as households having no more than 50 decimals of land. Mis-targeting ${ }^{2}$ was estimated around 4-6 per cent. Studies conducted in later years, however, report the extent of mis-targeting to lie between 20-30 per cent (Zaman 1996 and Mustafa 1995 for BRAC; Morduch 1998; Sen 1996 and Kamal 1996 for a broader study). How does one explain such large differences in these figures? One explanation could be that, over time, borrowers have bought land and graduated from the target to non-target group. The other explanation could be that over time mis-targeting has increased.

Both explanations are examined in this article using household survey data on 354 Grameen Bank borrowers in four villages of Madhupur Thana in Tangail. The possibility of graduation seems unlikely since there is a general negative relationship between membership length and land ownership. A close look at the data reveals that 1992 marks a watershed year. Seasonal loans were introduced in 1992 which could be held alongside the more common general loans. This expansion of the loan portfolio increased the average loan size per borrower, as well as the entry point loan size. At the same time, it is found that both the incidence and severity of mis-targeting are higher for post1992 entrants.

Traditionally, Grameen Bank's self-targeting mechanisms (such as small loan sizes, focus on women members, floor-seating during centre meetings, saluting and chanting slogans, etc.) have discouraged the participation of the more well-endowed (and possibly higher status) non-target group. It is hypothesised that rapid credit deepening through the introduction of seasonal loans has led to increased potential benefits for all the key stakeholders (the non-target group, the Grameen Bank, as well as the target group), encouraging non-target

\footnotetext{
I am grateful to Saurabh Sinha for providing extensive comments on earlier versions of this article. The usual disclaimers apply.
}

${ }^{2}$ Mis-targeting implies including those who, according to some pre-defined criterion, should not be included. This is similar to the type II error in hypotheses testing.

\section{Mis-}

Targeting by the

Grameen

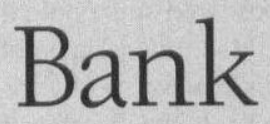

\title{
Imran Matin
}


group households to participate, thereby increasing the extent of mis-targeting.

The article is structured as follows. The second section tests for mis-targeting based on the 'graduation' argument. The third section provides evidence from the survey data about the extent of credit deepening since 1992. It also tests for the incidence and severity of mis-targeting among the post-1992 entrants. The results are analysed in the fourth section.

\section{Examining 'Graduation' Argument of Mis-Targeting}

The study uses a 1994-95 household survey of all households in four villages of Madhupur Thana of Tangail District. All these villages are served by the Madhupur Branch of Grameen Bank which is one of the first branches established by the bank in 1980 .

There are a total of 2,566 households in the four study villages. On dividing the entire sample into target group and non-target groups based on the household's current land ownership, it is found that more than two-thirds of the households (76.8 per cent) belong to the target group. Of these, more than half ( 54 per cent) do not have any NGO participation despite the high intensity of micro-credit intervention in the study area. ${ }^{3}$

Programme leakage can be estimated by calculating the proportion of non-target group households. Of the 354 households that joined Grameen Bank, slightly more than a quarter ( 25.4 per cent) of them did not belong to the target group at the time of survey. Such a measure however ignores the possibility of 'graduation' of target group households into nontarget group. This becomes a real possibility if households have been participating in a programme for some length of time.
GB borrowers in the study villages had been members for some time (the median membership length is eight years), and their 1994-95 land ownership might be different from that at the time of joining. However, land ownership is assumed to be stable due to a depressed land market, ${ }^{4}$ and serves as a good indicator of initial endowment position of participating households. The possibility that household land ownership might differ between the survey and start of membership is plausible, especially when membership length is high as is the case for GB borrowers in the study villages. Unfortunately, there is no information on land ownership of Grameen Bank households at the time of joining. However, information on the last land market transaction of households was collected during the survey. ${ }^{5}$ This information is used to categorise participating households and identify those whose entry point land ownership category is the same as that during the survey period. The overall land ownership change for all Grameen Bank households is shown in Table 1.

It is evident that:

- For 70 per cent GB households in the study area, the survey period land ownership can be used as their entry point land ownership. This is because 38 per cent of households had no land transaction, and 32 per cent households reported their last land transaction to have taken place before joining the Grameen Bank.

- For households that reported their last land market transaction to have taken place after joining Grameen Bank, under a certain assumption, there is no significant graduation from 'target group' (i.e. landless and functionally landless) to non-target group'. Only three households show such an 'upward' trend, i.e. 99 per cent of those households that belonged to target group at the time of the survey were in the target group when

\footnotetext{
${ }^{3}$ There were more than 30 NGOs serving the area and most of them had credit components. All of the nationally important micro-credit NGOs like BRAC, Proshika, ASA etc. operate in the study area, Tangail. Despite such a heavy NGO involvement, the fact that more than half of the 'target' group population is 'nonparticipant' is an indication that mere proliferation of credit interventions, most of which offer pretty much the same service, might not be all that relevant for a vast majority of the poor (see Greeley 1996 for a similar point).
}

\footnotetext{
4 On low turnover of land, Basu (1990: 33) provides an interesting explanation based on self-fulfilling theory. $\mathrm{He}$ argues that individuals hesitate to sell land because of the expectation that land turnover is low and it is this hesitation that in turn reinforces the low land turnover.

5 For each household, we have information on the
nature of the last land market transaction (whether
buying or selling land), year of transaction, size (in
decimals) of the transaction and the value (in taka).
} 
Table 1: Cross-Tab Between Entry Point and Survey Period Land Ownership

\begin{tabular}{|c|c|c|c|c|c|c|}
\hline \multicolumn{7}{|c|}{ Survey Period Land Group } \\
\hline \multicolumn{7}{|c|}{ (Row) } \\
\hline $\begin{array}{l}\text { Entry Point } \\
\text { Land Group } \\
\text { (Column) }\end{array}$ & Landless & $\begin{array}{l}\text { Function- } \\
\text { ally Landless }\end{array}$ & Marginal & Small & Medium & Total \\
\hline Landless & $\begin{array}{l}129 \\
(98)\end{array}$ & 2 & & & & 131 \\
\hline $\begin{array}{l}\text { Functionally } \\
\text { landless }\end{array}$ & $\begin{array}{l}44 \\
(34)\end{array}$ & $\begin{array}{l}83 \\
(64)\end{array}$ & 3 & & & 130 \\
\hline Marginal & 1 & 5 & $\begin{array}{l}55 \\
(89)\end{array}$ & 1 & & 62 \\
\hline Small & & & 1 & $\begin{array}{l}14 \\
(87)\end{array}$ & 1 & 16 \\
\hline Medium & & & & 2 & $\begin{array}{l}13 \\
(87)\end{array}$ & 15 \\
\hline
\end{tabular}

Notes: Figures in parentheses are percentage of row total.

Landless and functionally landless households ( $0-50$ decimals) together constitute the target group. Other categories are: marginal (51-100 decimals), small (101-150 decimals), and medium (above 150 decimals). 100 decimals $=1$ acre.

they joined. In general, except the entry point functionally landless households, we observe quite high levels of stability (the diagonal elements in Table 1). The incidence of downward mobility from non-target group to target group is also very low (only six households).

These two points suggest that land ownership status of households is fairly stable and the possibility of survey period 'non-target' group households belonging to 'target group' at the time of joining is limited for the Grameen Bank households studied. Thus, there is little evidence of graduation (from target group to non-target group) to explain the temporal difference in the estimates of mistargeting.

\section{Mis-Targeting Over Time: What Does the Survey Data Really Tell Us?}

This section is in two parts. It first provides evidence from the survey data about the extent of credit deepening since 1992. Using econometric tests, the second part tests for the increased incidence and severity of mis-targeting among the recent (i.e. post-1992) entrants. A simple means test is first used to confirm whether there are significant differences in landownership between preand post-1992 entrants. Subsequently, a multivariate regression is used to test whether the difference in landownership is indeed because of the year of joining.

\subsection{Rapid credit deepening: the evidence}

This section provides evidence of rapid credit deepening using loan size information from the study area. The introduction, in 1992, of the seasonal loan, which borrowers could hold in addition to the general loan, led to an unprecedented increase in the average loan size per borrower. Table 2 shows the trend in real loan size in the study area. It is evident that the increase in average loan per borrower during 1992-94 is mainly due to the nearly twofold increase in the size of seasonal loans. When the seasonal loan was introduced in 1992, the average size disbursed was low to begin with. However, by 1993, the average size of seasonal loan disbursed 
Table 2: Trend in Loan Size, 1992-94

\begin{tabular}{|l|l|l|l|}
\hline Variables & 1992 & 1993 & 1994 \\
\hline $\begin{array}{l}\text { Average loan per } \\
\text { borrower (Tk) }\end{array}$ & $8628(0.27)^{*}$ & $11215(0.29)$ & $11480(0.24)$ \\
\hline $\begin{array}{l}\text { Average size of general loan } \\
\text { (Tk) }\end{array}$ & $5331(0.33)$ & $5578(0.29)$ & $5336(0.25)$ \\
\hline $\begin{array}{l}\text { Average size of seasonal } \\
\text { loan (Tk) }\end{array}$ & $3297(0.28)$ & $5641(0.40)$ & $5881(0.33)$ \\
\hline $\begin{array}{l}\text { First year average loan per } \\
\text { borrower (Tk) }\end{array}$ & $6887(0.15)$ & $9736(0.12)$ & $10000(0.13)$ \\
\hline
\end{tabular}

Notes: Figures in parentheses are coefficients of variation.

All figures are in real terms with 1992 as the base year.

Deflaters have been calculated using Rural Price Index from Bangladesh Bureau of Statistics Report, 1997.

increased rapidly making the first year loan per borrower in 1993 about 1.5 times the level in 1992. Table 2 also shows the first year average loan size per borrower.

This process of rapid credit deepening in the study area seems to be part of an overall trend within Grameen Bank, and is corroborated by other studies. Todd (1996: 178-80) reported that:

1993 was the year of a giant leap in loan disbursement in Tangail Zone. The seasonal loan which matched and sometimes exceeded the general loan more than doubled total disbursement in 1993. More than 50 crore taka was disbursed in the new seasonal loans ... check the monthly collection sheet at the branch office ... most of the members are now carrying a weekly repayment of between 250 to 400 taka.

Rahman (1997: 12) found that one Grameen Bank branch manager expressed his concern over increased size of loans disbursed to the managing director:

Recently there is an intense competition among different managers to increase their loan disbursement. Increasing disbursement is important for the bank but we must not forget the capabilities of our members. If we continue with our present attitudes then the result will be serious.

\subsection{Mis-Targeting among post-1992 entrants}

The sample of Grameen borrowers is divided into two groups, with group A consisting of households which joined before 1992, and group B comprising households that joined after 1992. Table 3 presents the result of differences in means and proportions test on some relevant variables. The results suggest that there are siginificant differences between the two groups in all variables. There is also a significant decline in the proportion of group B households belonging to the target group.

Table 4 shows the results of an OLS regression analysis which confirms that members joining in or after 1992 have a higher current landownership than those who joined in earlier years. That is, inclusion error has worsened since 1992. The model suggests that post-1992 Grameen households own, on average, 23 decimals more land than earlier entrants.

It is possible that despite the increase in the incidence of inclusion error, the actual severity is low. This could be the case if most non-target group entrants are only just outside the target group threshold. Table 5 compares the land ownership of the two groups to test for the difference in the severity of the inclusion error. 
Table 3: Differences in Means and Proportions between 2 Groups of GB Households

\begin{tabular}{|l|l|l|l|}
\hline Variable & $\begin{array}{l}\text { Group A (pre 1992) } \\
\text { households (n=269) }\end{array}$ & $\begin{array}{l}\text { Group B (post-1992) } \\
\text { households (n=85) }\end{array}$ & t-test \\
\hline $\begin{array}{l}\text { Average land owned per } \\
\text { household (in } \\
\text { decimals) }\end{array}$ & $\begin{array}{l}39.0 \\
(1.9)\end{array}$ & $\begin{array}{l}97.9 \\
(1.2)\end{array}$ & $4.4^{* * *}$ \\
\hline $\begin{array}{l}\text { Average land operated per } \\
\text { household (in } \\
\text { decimals) }\end{array}$ & $\begin{array}{l}113.9 \\
(1.4)\end{array}$ & $\begin{array}{l}173.7 \\
(1.1)\end{array}$ & $2.29^{* *}$ \\
\hline $\begin{array}{l}\text { AME land owned per } \\
\text { household (in decimals) }\end{array}$ & $\begin{array}{l}8.6 \\
(1.67)\end{array}$ & $\begin{array}{l}19.9 \\
(1.2)\end{array}$ & $4.37^{* * *}$ \\
\hline Proportion of target group & $\begin{array}{l}0.71 \\
(0.63)\end{array}$ & $\begin{array}{l}0.49 \\
(1.02)\end{array}$ & $3.07^{* * *}$ \\
\hline
\end{tabular}

Notes: Figures in parentheses are coefficients of variation.

*** significant at $1 \%$

** significant at $5 \%$

Table 4: Results of an OLS Regression on Sample of Current GB Members

\begin{tabular}{|l|l|l|l|}
\hline \multicolumn{1}{|c|}{ Variable } & \multicolumn{2}{c|}{ Dependent Variable Current Land Owned in Decimals. N=354 } \\
\hline & Regression coefficient & t-ratio & Significance \\
\hline Constant & -120.71 & -7.32 & 0.000 \\
\hline Adjusted family size & 82.47 & 6.94 & 0.000 \\
\hline $\begin{array}{l}\text { Household head's education } \\
\text { (years of schooling) }\end{array}$ & 6.65 & 6.51 & 0.001 \\
\hline $\begin{array}{l}\text { Household head's age on } \\
\text { joining }\end{array}$ & 1.66 & 5.71 & 0.000 \\
\hline $\begin{array}{l}\text { Membership dummy (1 if } \\
\text { joined in or after 1992, } 0 \text { if } \\
\text { otherwise) }\end{array}$ & 23.44 & 2.6 & 0.010 \\
\hline $\begin{array}{l}\text { Village dummy } 1 \text { (1 if } \\
\text { Jataban, 0 if otherwise) }\end{array}$ & 52.43 & 4.73 & 0.000 \\
\hline $\begin{array}{l}\text { Village dummy 2 (l if } \\
\text { Biprabari, 0 if otherwise) }\end{array}$ & 26.61 & 3.63 & 0.085 \\
\hline $\begin{array}{l}\text { Village dummy 3 (1 if Teki, } \\
\text { 0 if otherwise) }\end{array}$ & 45.84 & 1.73 & 0.000 \\
\hline \begin{tabular}{l} 
Adjusted R squared \\
\hline
\end{tabular} & 0.32 & & \\
\hline
\end{tabular}


Table 5: Land Ownership Distribution of GB Member Households (per cent)

\begin{tabular}{|lr|l|l|}
\hline Landownership Class & $\begin{array}{l}\text { Group A (pre-1992) Households } \\
(\mathbf{n = 2 6 9 )}\end{array}$ & $\begin{array}{l}\text { Group B (post-1992) Households } \\
(\mathbf{n}=85)\end{array}$ \\
\hline Landless & $(1)$ & 48.5 & 30.2 \\
\hline$>0$ to $\leq 50$ decimals & $(2)$ & 30.4 & 18.9 \\
\hline Target Group & $(1+2)$ & 78.9 & 49.1 \\
\hline$>50$ to $\leq 100$ decimals & $(3)$ & 8.3 & 18.9 \\
\hline$>100$ decimals & $(4)$ & 12.7 & 32.1 \\
\hline Non-target Group & $(3+4)$ & 21.0 & 51.0 \\
\hline
\end{tabular}

The extent of mis-targeting in the pre-1992 group of GB members is 21 per cent. It increased to more than 50 per cent among the post-1992 members. More importantly, nearly one-third of the post-1992 member households have more than 100 decimals of land. Thus, there is an increase in both the incidence and severity of mis-targeting among the post-1992 GB members.

\section{Conclusion}

The previous section provided evidence of two ostensibly independent processes since 1992: rapid credit deepening, and an increase in the incidence and severity of mis-targeting. Using a demand and supply framework, it is argued that there is a causal linkage between them. For, increasing incidence and severity of mis-targeting is a consequence of credit deepening. Introduction of a seasonal loan in 1992 is considered as an exogenous factor for the purposes of the present research. Once an increase in the average loan size is taken as a 'given', it is not difficult to see how it might lead to increased incentives for participation by the non-target (NTG) group (i.e. mis-targeting). As indicated in Table $6,{ }^{\circ}$ all the three stakeholders stand to benefit from NTG participation.

Further research based on a more representative sample is surely needed that will examine the temporal dimension of targeting with reference to the changes in the contract and the organisational values (both implicit and explicit). As micro-credit $\mathrm{NGO}_{s}$ in Bangladesh are increasingly moving towards providing differentiated financial services (besides credit) and experimenting with various types of innovative contract design (Rutherford 1995), a natural extension of this work would be to examine how these affect participation incentives. Conceptualising mis-targeting through direct mechanisms of selection by bank staff according to some pre-set criterion might be missing out the importance of self and peer selection incentives (the indirect selection mechanisms) that a joint liability contract gives rise to. An understanding of these incentives and the ways in which they are affected by policy (implicit or explicit) changes could hold important lessons for contract design and overall policy.

- This table was suggested by Saurabh Sinha. 
Table 6: Incentives for Non-target Group Participation

\begin{tabular}{|l|l|l|}
\hline Stakeholder & Benefit & Outcome \\
\hline Non-target Group Households & $\begin{array}{l}\text { Increased loan size (at relatively cheap } \\
\text { rate) can be productively employed in } \\
\text { micro-enterprises }\end{array}$ & $\begin{array}{l}\text { Demand for MFI membership as } \\
\text { costs' of participation reduced }\end{array}$ \\
\hline Microfinance Institution (MFI) & $\begin{array}{l}\text { Reduced risk of default, likely to } \\
\text { deposit more savings, demand larger } \\
\text { loans, and thereby improve the } \\
\text { branch's self-financing ratio }\end{array}$ & $\begin{array}{l}\text { Supply of MFI membership to NTG } \\
\text { through lax screening and leniency in } \\
\text { strictly observing the eligibility crite- } \\
\text { rion by bank workers (see Zaman } \\
\text { 1996) }\end{array}$ \\
\hline Target Group Households & $\begin{array}{l}\text { Increased mutual insurance with help } \\
\text { from 'wealthier' (non-target) group } \\
\text { members to tide over occasional loan } \\
\text { repayment difficulties (see Zaman } \\
\text { 1998); possible to negotiate elite resis- } \\
\text { tance (see: Kamal 1996; Sen 1996) }\end{array}$ & Reduced internal screening \\
\hline
\end{tabular}

\section{References}

Basu, K., 1990, 'Agrarian Structure and Economic Underdevelopment', Fundamentals of Pure and Applied Economics, 37, Harwood Acdemic Press, New York.

Greeley, M., 1996, 'Poverty and well-being: problems for poverty reduction in role of credit', in G. Wood and I. Sharif (eds.), Who Needs Credit? Poverty and Finance in Bangladesh, University Press Lid, Dhaka.

Hossain, M., 1988, 'Credit for Rural Poverty: The Grameen Bank in Bangladesh', International Food Policy Research Institute Research Report, 65.

Hulme, D., R. Montgomery and D. Bhattacharya, 1996, 'Credit for the poor in Bangladesh : the BRAC Rural Development Programme and the Government Thana Resource Development and Employment Programme', in D. Hulme and P. Mosley (eds.), Finance Against Poverty, Vol. 2 , Routledge, London: 94-176.

Ito, S., 1998, 'The Grameen Bank and peer monitoring: a sociological perspective', in I. Matin and $S$. Sinha (eds.), Proceedings of a Workshop on MicroFinance: Implications for Policy, Poverty Research Unit at Sussex (PRUS) Working Paper No. 3, Sussex: 175-90.

Kamal, A., 1996, 'Poor and the NGO process: adjustment and complicities', in H.Z. Rahman et al., (eds.), 1987-1994: Dynamics of Rural Poverty in Bangladesh, Bangladesh Institute of Development Studies (BIDS), Dhaka.
Matin, I., 1996, 'Renegotiation of joint liability: notes from Madhupur', in G. Wood and I. Sharif (eds.), Who Needs Credit? Poverty and Finance in Bangladesh, University Press Ltd., Dhaka.

Matin, I., 1997, 'Repayment Performance of Grameen Bank Borrowers in Madhupur: The Unzipped State', Savings and Development, Vol. 22, No. 4.

Montgomery, R., 1995, 'Disciplining or Protecting the Poor? Avoiding the Social Costs of Peer Pressure in Solidarity Group Micro-Credit Schemes', paper presented at the Reading Conference on 'Finance Against Poverty', Reading, UK.

Morduch, J., 1998, 'Does Microfinance Really Help the Poor? Unobserved Heterogeneity and Average Impacts of Credit in Bangladesh', mimeo, Harvard University.

Mosley, P., 1996, 'Indonesia : BKK, KURK and BRI Unit Desas', in D. Hulme and P. Mosley (eds.), Finance Against Poverty, Vol. 2, Routledge, London: 32-93.

Mustafa, S. et al., 1995, 'Beacon of Hope: An Impact Assessment of BRAC's Rural Development Programme', mimeo, Bangladesh Rural Advancement Committee, Dhaka.

Rahman, H.Z., 1996, 'Crisis, income erosion and coping', in H.Z. Rahman, et al. (eds.), 1987-1994 : Dynamics of Rural Poverty in Bangladesh, Bangladesh Institute of Development Studies (BIDS), Dhaka.

Rutherford, S., 1995, 'The Savings of the Poor: Improving Financial Services in Bangladesh', mimeo, Dhaka. 
Sen, B., 1996, 'Development assistance and poverty : a view from below', in H.Z. Rahman et al. (eds.), 1987-1994: Dynamics of Rural Poverty in Bangladesh, Bangladesh Institute of Development Studies (BIDS), Dhaka.

Stiglitz, J. and K. Hoff, 1990, 'Introduction: Imperfect Information and Rural Credit Markets-Puzzles and Policy Perspectives', The World Bank Economic Review, Vol. 4 No. 3: 235-250.

Todd, H., 1996, Women At the Centre: Grameen Bank Borrowers after One Decade, Westview Press, Colorado, USA.

Wenner, M., 1995, 'Group Credit: A Means to Improve Information Transfer and Loan Repayment Performance', Journal of Development Studies, Vol. 32 No. 2: 263-281.

Zaman, H., 1996, 'Micro-credit programmes: who participates and what does it matter?', in G. Wood and I. Sharif (eds.), Who Needs Credit? Poverty and Finance in Bangladesh, University Press Ltd., Dhaka.

Zaman, H., 1998, 'Can Mis-targeting be Justified? Insights from BRAC's Micro-Credit Programme', IDS Bulletin, Vol. 29 No. 4.

Zeller, M. and M. Sharma, 1996, 'Determinants of Repayment Performance in Innovative Group-Based Credit Systems for the Poor: The Cases of BRAC, ASA and RDRS in Bangladesh', FCND Discussion Paper No. XX, IFPRI. 